\title{
Şizofrenide Psikojenik Polidipsi için Amisülpirid Tedavisi: Olgu Sunumu
}

\author{
Amisulpiride Treatment for Psychogenic Polydipsia in Schizophrenia: A Case Report
}

\author{
Ayşegül ŞAHİN EKİCI \\ (i) 0000-0001-5788-1484 \\ Şengül ŞAHIN \\ (1) 0000-0002-5371-3907 \\ Gülçin ELBOĞA \\ (1) 0000-0003-3903-1835 \\ Abdurrahman ALTINDAĞ \\ (ic) 0000-0001-5531-4419
}

Gaziantep Üniversitesi Tıp Fakültesi Ruh Sağlığı ve Hastalıkları Anabilim Dalı, Gaziantep

\section{Sorumlu Yazar \\ Corresponding Author Ayşegül ŞAHIN EKİCi asahinekici@gmail.com}

Geliş Tarihi / Received : 01.12.2018

Kabul Tarihi / Accepted : 11.02.2019

Çevrimiçi Yayın Tarihi /

Available Online

\begin{abstract}
ÖZ
Psikojenik polidipsi veya kendiliğinden indüklenen su zehirlenmesi, kompulsif su içimini tanımlamak için kullanılır. Mental hastalıklarda nadir görülen bir durum değildir. En sık kronik şizofrenide görülür. Tedavisi etiyolojiye ve tablonun ciddiyetine göre düzenlenir. Hafif vakalarda su kısıtlaması ve hastanın eğitimi yeterlidir, ağır olgularda tedavide su kısıtlaması, tuz solüsyonu infüzyonu, diüretikler, hiponatremi kaynaklı nöbetlerin kontrolünün sağlanması için antikonvülsan ilaç uygulaması yapılır. Akut klinik tablonun tedavisinden sonra altta yatan primer psikiyatrik hastalığın tedavisi yeniden düzenlenmelidir. Bu yazıda şizofreni tanısıyla 14 yıldır takip edilen ve psikojenik polidipsi tanısı alan ve amisülpirid tedavisi ve sıvı kısıtlaması ile başarıyla tedavi edilen 39 yaşında bir erkek hasta sunulmuştur.
\end{abstract}

Anahtar kelimeler: Psikojenik polidipsi; şizofreni; amisülpirid.

\section{ABSTRACT}

Psychogenic polydipsia or self-induced water poisoning is used to describe compulsive drinking. It is not a rare condition in mental disorders. Chronic schizophrenia is the most common reason. Treatment should be organized according to the etiology and severity of the case. In mild cases, water restriction and patient education is sufficient, but In severe cases, are recommended water restriction, salt solution infusion, diuretics and application of anticonvulsant drugs to control hyponatremia-induced seizures. The treatment of the underlying primary psychiatric disease should be rearranged after the treatment of the acute clinic symptoms. In this article, we present a 39 -year-old male patient with a diagnosis of chronic schizophrenia with psychogenic polydipsia and was treated successfully with amisulpride and fluid restriction.

Keywords: Psychogenic polydipsia; schizophrenia; amisulpiride.

\section{GİRIŞ}

Psikojenik polidipsi veya kendiliğinden indüklenen su zehirlenmesi, kompulsif su içimini tanımlamak için kullanılır. Antidiüretik Hormon (ADH) üretiminde ya da salınımında bozukluk olmaksızın susuzluk hissi kontrolünde bozulma vardır. Polidipsi ve poliüriyi takiben hiponatremi gelişebilir. Su intoksikasyonuna bağlı bulantı kusma, deliryum, nöbet ve komaya kadar ilerleyen bulgular ortaya çıkabilir (1). Psikojenik polidipsinin psikiyatri kliniklerinde yatan hastaların \%6-20'sinde görüldüğü, en sıklıkla şizofrenide (\%80) olmak üzere mental retardasyonda, bipolar bozuklukta, alkol bağımlılığında, yeme bozukluklarında ve organik mental bozuklukta da görülebileceği bildirilmiştir $(2,3)$. Tedavide sıvı kısıtlamasının yanı sıra demeklociklin, propranolol, kaptopril ve nalokson gibi çeşitli farmakolojik ajanlar kullanılmaktadır. Özellikle psikotik hastalarda olmak üzere tedavide antipsikotik kullanımı ile iyileşen olgular bildirilmiştir (1-5). Yapılan literatür taramasında bir atipik antipsikotik olan amisülpiridin kullanımıyla ilgili çalışma bulunamamıştır. Bu yazıda şizofreni tanısıyla takipli psikojenik polidipsi hastasının amisülpirid tedavisi ve sıvı kısıtlaması ile başarılı bir şekilde tedavisi sunulmaktadır. Olgunun yazılı olarak bilgilendirilmiş onamı alınmıştır. 


\section{OLGU SUNUMU}

Otuz dokuz yaşında erkek hasta polikliniğe son 2 aydır artış gösteren, saldırganlık, öz bakımında azalma, komşuları tarafindan kötülük göreceğine dair yoğun persekusyon ve paranoid sanrılarılarının olması nedeniyle başvurdu. Alınan anamnezde hastanın evin etrafını saran askerler gördüğü, yiyeceklerine zehir katıldığını düşündüğü için 4 aydır yalnızca domates, salatalık ve ekmek yediği öğrenildi. Babası, hastalığının başlangıç döneminde bir televizyon programında su içmenin önemini anlatan bir doktor tavsiyesi duyduktan sonra hastanın sık sık su içtiğini, vücudundaki zehrin ve ilaçların ancak bu şekilde temizlendiğine inandığını söyledi. Şebeke suyunu içmek istemiyor, yalnızca paketli şişe su içiyordu. Ondört yıldır şizofreni tanısıyla takipli hasta, 2 yıldır bütün ilaçlarını almayı reddediyordu.

Ruhsal muayenesinde; duygudurum irritabl, duygulanım labil, çağrışımları dağınık, düşünce içeriğinde paranoid, persekusyon ve referans sanrıları mevcut, algıda işitsel ve görsel halüsinasyonlar var, düşünce sürecinde enkoherans ve verbigerasyon olup yargılama bozulmuş, içgörüsü yoktu.

Zuklopentiksol dekonoat $200 \mathrm{mg} / 15$ günde bir enjeksiyon, olanzapin $20 \mathrm{mg} /$ gün ve günde iki defa $10 \mathrm{mg}$ haloperidol ampul $+5 \mathrm{mg}$ biperiden enjeksiyon tedavisi başlandı. Eksitasyonları ve saldırganlığı azalan hastanın haloperidol + biperiden enjeksiyonu kesildi.

Servis gözlemi ve vizitleri sırasında çok miktarda su içmesi ve sık idrara çıkması olan hastanın takiplerinde yaklaşık sıvı alımının 12 lt/gün olduğu belirlendi. Yapılan tetkiklerinde serum sodyum değeri: $132 \mathrm{mEq} / \mathrm{lt}$ olarak saptand. İdrar dansitesi 1000 olarak ölçüldü. Psikojenik polidipsi öntanısı ile hastaya sıvı kısıtlama testi yapıldı. Aldığı sıvı miktarı 4lt/güne kadar azaltıldı. Sivı kısıtlama testiyle idrar dansitesi 1010 değerine yükseldi.

Psikotik bulgularında belirgin gerilemesi olmayan ve aşırı sıv1 tüketimi devam eden hastanın tedavisinde; klozapin $25 \mathrm{mg} /$ gün başlanarak gün aşırı $25 \mathrm{mg}$ artış yapılıp 200 $\mathrm{mg} /$ üne çıkıldı. Klozapin tedavisi sırasında polidipsi tablosu devam etti. Sedasyon ve hipersalivasyon yan etkileri sebebiyle daha fazla doz artışını tolere edemediği için klozapin ve diğer oral tedavileri kesilerek tedavisine amisülpirid $800 \mathrm{mg} /$ gün eklendi. Tedavisine eklenen amisülpirid sonrası psikotik bulguları geriledi. Sıv1 kısıtlama konusunda uyumu arttı. Şebeke suyunun zehirli olduğuna dair olan paranoid sanrıları kalmadı.

\section{TARTIŞMA}

Olgumuzda klozapin tedavisine yanıt alınamaması sonrasında hastaya amisülpirid tedavisi başlanmış, tedavi sonrası hastada psikojenik polidipsi tablosu gerilemiş olup takiplerde sıvı tüketimi 5 lt/güne kadar inmiştir.

Tipik antipsikotikler polidipsik davranışın kötüleşmesi ile ilişkilidir, yakın zamanda atipik antipsikotiklerin yararlı olduğu bildirilmiştir. Ancak sonuçlar hala karışık ve tartışmalıdır. Risperidon ve olanzapinin açıkça etkili olmadığ1 anlaşılmaktadır; klozapin semptomları iyileştirebilir, ketiapin bugüne kadar yeterince incelenmemiştir (3).

Antipsikotiklerin psikojenik poldipside etki mekanizmasının tam olarak nasıl olduğu bilinmemektedir. Amisülpirid bu hastada sıvı almayla ilgili güçlü hezeyanı iyileştirmede klozapin haloperidol ve olanzapindan daha etkili olup, hezeyanları düzeltmesinin mevcut tabloyu iyileştirmede katkısı olabilir.

Sonuçta atipik bir antipsikotik olan amisülpiridin, klozapin gibi psikojenik polidipsi olguları üzerinde alternatif bir tedavi seçeneği olabileceği görülmekte, ancak terapötik kullanımı için sistematik değerlendirme ve kontrollü çalışmalar gerekmektedir.

\section{KAYNAKLAR}

1. Bhatia MS, Goyal A, Saha R, Doval N. Psychogenic polydipsia-management challenges. Shanghai Arch Psychiatry. 2017;29(3):180-3.

2. Altındağ A, Yanık M, Nebioğlu M. Bipolar bozuklukta psikojenik polidipsi: Bir olgu sunumu. Klinik Psikofarmakoloji Bülteni. 2004;14(2):79-82.

3. Costanzo ES, Antes LM, Christensen AJ. Behavioral and medical treatment of chronic polydipsia in a patient with schizophrenia and diabetes insipidus. Psychosom Med. 2004;66(2):283-6.

4. Rao N, Venkatasubramanian G, Korpade V, Behere R, Varambally S, Gangadhar B. Risperidone treatment for polydipsia and hyponatremia in schizophrenia: a case report. Turk Psikiyatri Derg. 2011;22(2):123-5.

5. Kruse D, Pantelis C, Rudd R, Quek J, Herbert P, McKinley M. Treatment of psychogenic polydipsia: comparison of risperidone and olanzapine, and the effects of an adjunctive angiotensin-II receptor blocking drug (irbesartan). Aust N Z J Psychiatry. 2001;35(1):65-8. 